\title{
A FUDAMENTAL CONTRADICTION IN SIDGWICK'S THE METHODS OF ETHICS
}

GEORGE W. ROBERTS

University of Kansas

\section{Sidgwick's Conflict of Principle}

In The Methods of Ethics ${ }^{1}$ Sidgwick describes a certain conflict in ethics as "a fundamental contradiction" and as "the profoundest problem in Ethics." 2 This conflict he identifies in several ways; it is the problem of "the relations of Interest and Duty," and it resolves, for him, into the " 'Dualism of the Governing Faculty'; or as I should prefer to say, the "Dualism of the Practical Reason'" as between "the natural end of action-private happiness, and the end of duty-general happiness." "3ight is available on Sidgwick's views about this conflict not only in the body of The Methods of Ethics but also in the sketch Sidgwick made of the development of his ethical views incorporated in the preface to the 6th edition of that work. The phrase "a fundamental contradiction" is not used in this sketch, but there is no doubt that this problem of conflict is central to the evolution Sidgwick describes, and that the sketch throws light on Sidgwick's conception of this problem and its role in his thought."

The problem was in one form implicit in Sidgwick's acceptance, at an early stage in the development of his views, of "two strands of Mill's doctrine," viz., what Sidgwick

1 Henry Sidgwick, The Methods of Ethics, 7th edition, 1907.

2 Ibid., p. 508, for "a fundamental contradiction".

3 Ibid., pp. xviii-xix, for the first quotation. The second quotation is from ibid., p. xv.

4 Ibid., pp. xv-xxi, for Sidgwick's sketch. 'The phrase "a fundamental opposition" occurs in the sketch at page $\mathbf{x x}$. 
came to call Psychological Hedonism and Ethical Hedonism. Indeed Sidgwick's first steps beyond Mill's doctrine as he conceived it were prompted, according to the sketch, by a realization that the egoistic and utilitarian strands of Mill's hedonism did not cohere. The effect of this realization, combined with Sidgwick's desire for a rational, philosophical resolution of the incoherence, was Sidgwick's acceptance of an element of Intuitionism. It was this doctrine of morals from which he had turned with relief to Mill, in order to escape the pressure of what he felt was an external and arbitrary code of duties, "doubtful and confused"; but he now found himself a utilitarian on an intuitional basis.

At this point Sidgwick again read Kant and was impressed with "the truth and importance of his fundamental maxim," though not with its metaphysical basis in Kant's doctrine of freedom, which Sidgwick held involves a confusion between two different senses of that term. Despite his agreement with Kant on the categorical imperative, Sidgwick felt that it was not sufficient for practical guidance. As the supreme practical maxim Sidgwick still accepted the Principle of Utility, which he had learned from Mill. He departed from both Mill and Kant, however, on the question of the reasonableness of self-love, to which both these philosophers in different ways gave, he thought, insufficient acknowledgment. In this state of mind he once again read Butler. Though differing from Butler on the soundness of the utilitarian principle, he found Butler's views as to the reasonableness of self-love to be in agreement with his own. Moreover, Sidgwick held that the Kantian imperative is not sufficient to exclude rational self-love as a principle. Sidgwick's final disposition of the conflict of duty and interest is, he says, the same made by Butler and Kant. This is the assumption of the moral governance of the world, in the sense of a postulate of divine rewards for virtue or punishments for vice in another life beyond "mundane experience." 5

5 The two preceding paragraphs paraphrase some relevant parts of Sidgwick's sketch, ibid., pp. xv-xxi. 
Sidwick seems inclined, then, to use two different procedures in resolving this conflict. The first is an appeal to intuition to settle the question whether general happiness or self-love is to be the finally overriding, ultimate moral end; the result is the suppression of egoism where it conflicts with general utility. ${ }^{6}$ The second procedure is the postulate of supernatural sanctions.

This article is concerned exclusively with Sidgwick's second procedure. It elaborates an hypothesis about the nature of the conflict between Sidgwick's principles that is compatible with this procedure of a postulate of supernatural sanctions to eliminate the inconsistency of the principles. But the merits of this hypothesis will not be finally settled here, though it will be defended against certain objections. Also Sidgwick's second procedure will be distinguished from an alternative mode of removing conflicts of principle that Sidgwick does not employ.

\section{An Hypothesis about the Conflict of Sidgwick's Principles}

We commence, then, with the statement of a hypothesis as to the types of contradiction that are to be found between Sidgwick's egoistic and utilitarian principles. This hypothesis is designed to set out as fully and explicitly as possible the way in which Sidwick might best have begun to defend

- For the first approach, see, for example, ibid., p. xii. For the second approach, see, for example, ibid., p. xx. This is confirmed by, for example, ibid., pp. x-xi.

7 Moore and Broad maintain against Sidgwick that the inconsistency between the principles is irremovable by any postulates as to the facts, natural or supranatural. For G. E. Moore's criticism of Sidgwick's views on his "profoundest problem of Ethics," see Principia Ethica (1903), Chapter III, "Hedonism," Section 62, pp. 102-104. C. D. Broad's similar critique of Sidgwick is found in various places; fully developed in Five Types of Ethical Theory (1930), Chapter VI, "Sidgwick," pp. 143-256, especially pp. 158-161 and pp. 253-256; set out less fully in "Henry Sidgwick" in Ethics and the History of Philosophy (1952), pp. 49-69, especially pp. 65-67; and treated rather summarily in Broad's article, "The Local Historical Background of Contemporary Cambridge Philosophy," in British Philosophy in the Mid-Century (edited by C. A. Mace), pp. 13-64, especially pp. 48-49. These criticism of Sidgwick will be discussed in a subsequent article. 
his postulational treatment of his fundamental problem of conflict of principles in ethics, against those who have argued that the problem is an insoluble one that is not affected by Sidgwick's postulate.

The hypothesis may be presented in a series of three assertions:

(1) The egoistic and utilitarian principles are in possible practical contradiction. This is to mean that it is not logically impossible for there to exist circumstances and connections in which at least one of the actions essential, with those circumstances and connections, to the realization of the end of one of the principles, is other than and exclusive of an action that is equally necessary to the accomplishment of the end of the other principle.

(2) The egoistic and utilitarian principles are in actual practical contradiction in that conditions actually occur and are likely to continue to occur that, so far as we consider simply the accomplishment of either end inside the limits of mundane experience, afford suitable premisses in actual fact to permit, upon addition of the principles in question, the deduction of contrary statements as to what certain particular actions should be.

(3) Yet, taken quite by themselves, neither the egoistic and the utilitarian principles, which enjoin the pursuit of ends not in themselves logically impossible, and not such that the accomplishment of one of these ends is as a matter of logic inconsistent with that of the other, could be sufficient material for the deduction of any inconsistent statements at all as to what should be done. Such a derivation requires the addition of premisses concerning circumstances and causal connections that attach to some occasion of action as a matter of contingent fact.

The first hypothesis about the conflict of Sidgwick's principles states, then, (1) that the principles are in possible practical contradiction, (2) that the principles are also in actual practical contradiction, and (3) that the principles 
are not directly inconsistent with one another. According to this hypothesis, the two sorts of inconsistency mentioned in the first two assertions are the only sorts of inconsistency that hold between the two principles.

It should be noted that in (3) the term "actual practical contradiction" has been defined in a narrow sense, with reference to conflicts that occur in mundane experience. The term may also be used in a wider sense, in reference to conflict in an actual case with respect to all those things and circumstances involved, whether these things are to be found in mundane experience or not. It is only in this wider sense that Sidgwick's postulate of the moral governance of the world can remove the apparent actual practical contradiction of his principles.

\section{The Elimination of Certain Difficulties with the Hypothesis}

We have next to consider some reasons why one might still want to say, even after these distinctions are made, that somehow Sidgwick's principles are just contradictory, inconsistent by themselves, and not only in the presence of certain additional assumptions of contingent fact. First, it should be observed that such an objection might rest on a particular form of statement of the principles. We are now obliged to consider at some length how this particular difference of formulation can be, or seem to be, significant.

Egoism, it might be said, is the doctrine that one is only obligated to do those things that are most conducive to the greatest happiness one can have in the whole of one's own life, while utilitarianism is the doctrine that one is obligated only to do those things that are most conducive to the greatest happiness attainable in the whole of sentient creation throughout its entire existence. These principles might be thought to be logically incompatible directly and by themselves, without reference to any further non-analytic assumptions. It might also be thought, however, that the formulation of 
these principles that substitutes "obligated" for "only obligated" would not involve them in inconsistency without further non-logical premisses, but would remove them from the inconsistency consequent on the other formulation.

But if it is agreed that in this new formulation the principles are not contradictory to one another in themselves, must it not also be agreed that no concrete obligation follows from the principles in the first formulation? Surely it must be granted that no statement of an obligation to do or refrain from doing any particular action whatever in the actual world is deducible even from the first, stronger formulation of the principles without the added specification of the contingent circumstances and causal consequences of some action relative at least to its promotion of or detraction from the ends of these principles?

The different formulations of the principles are, nonetheless, different in logical force and therefore non-equivalent. The firs formulation might possibly appear preferable as an expression of Sidgwick's intentions in stating these principles. Moreover, the first, strong formulation of the principles does seem to produce the appearance of immediate contradiction between them. It might be suggested that what seems to recommend the first, or strong formulations as an interpretation of Sidgwick is the overriding character Sidgwick wants to assign each of the principles as referring to an ultimate rational aim. On reflection, however, we may think we are able to discern in another considerations a sufficient cause, and some justification, for the appearance of strengthening and of heightened contradiction. The additional elements of contradiction between the principles in their strong formulations, and therefore the force of "only" in them, can perhaps be described in the following way. In cases in which whatever we do within some range of choice the attainment of the egoistic end is not affected, the strong formulation of the egoistic principle entails that we have no obligations whatever to do one action rather than 
another within this range of choice in these cases. Buit it is still possible that choice at some specific point in this range is vital to the utilitarian end. From the utilitarian principle it follows that we do, in such a case, have an obligation not to do some actions in this range. Thus further cases of possible practical contradiction and perhaps also of actual practical contradiction arise to separate the two principles, but essentially the type of relation between the principles, logically considered, remains the same. The strong formulation does not make the principles any more contradictory in themselves, as its force is entirely absorbed in the additional implications that have just been indicated. So the dissatisfaction we may feel in the conjunction of the principles may still seem to have as its objective sources only the types of contradiction that are laid down in the first hypothesis. Moreover, the added force of the egoistic principle in the strong formulation is no way essential to it and in no way affects its possible practical consequences for actions that have any positive or negative bearing on its end. Further consideration of it will therefore be omitted.

But the whole question of the inconsistency of the principles by themselves seems to admit of further simple but seductive fallacies. If our examination of the subject of the relation of the two principles is to be reasonably exhaustive, some account of these likely though elementary fallacies is necessary, An account is given in the dialogue that follows:

$(\alpha)$ Still I think a man cannot serve two masters. The very idea of having them is somehow repugnant, for when you come to the parting of the ways you must cleave to the one and depart from the other.

$(\beta)$ Before you pass with rhetorical vagueness from unstated premisses to erroneous conclusions let me present a complete account of what you have in mind as premisses, things that are indeed facts. In terms of the matters described in statement (3) of the first hypothesis, your case, precisely put, is this: from the principle $A$, that one ought to do what 
conduces to $X$, and the principle $B$, that one ought to do what conduces to $Y$, together with the contingent statements as to the facts, $C$, to the effect that the act open to one's choice is conducive to $X$ and non-conducive to, indeed exclusive of, $Y$, it follows logically both that (i) you ought to do $Q$ and that (ii) you ought not to do $Q$ but ought to do something else instead. Also, it follows that (iii) if you do not do $Q$, then you have not acted in accordance with $A$, though you have acted in accordance with $B$, and that (iv) if you do $Q$; then you have acted in accordance with $A$, though not in accordance with $B$. Further, (v) if you maintain you ought to do $Q$, then you cannot accept $B$, but may accept $A$, while (vi) if you maintain you ought not to do $Q$, or even that you have no obligations with respect to doing $Q$ or not doing $Q$, then you cannot accept $A$; if you merely maintain you ought not to do $Q$, then you may accept $B$, while even $B$ cannot be accepted if you deny that in this case you have any obligations. In (v) and (vi) we assume, however, that you accept some suitable statement $C$ concerning the contingent factual situation. Assuming $C$ you cannot, if you hold (i) that you ought to do $Q$ or (ii) that you ought not to do $Q$, also maintain that $A$ and $B$ are true together. Finally, if you make no moral judgment on your action you need not reject either principle.

$(\alpha)$ The point of all this is just that once you have accepted the two principles and a particular sort of account of the facts of a situation of action, you are committed, logically tied, to two contrary particular judgments on what ought to be done in that situation. Each principle, moreover, determines us to accept its consequences, and therefore determines us to reject the other principle of opposite consequences.

$(\beta)$ You still need the now tiresome reminder that the principles do not imply any statements of what ought to be done in particular cases without some such contingent factual assertion as $C$. You have done nothing, aside from slipping fallaciously into the denial of this point, to show that the 
account that has been given of the conflict of Sidgwick's principles as consisting simply in possible or actual practical contradiction needs to be supplemented in any way.

$(\alpha)$ Well, I can only reply by ringing changes on the fact that after all in such cases as we have been discussing we have to choose which principle we are to continue to accept in its full force and which to modify. Though one of the principles has been wounded the pair again harmonizes in practice till further notice of another case of conflict, in which we may decide to retain the previously modified principle in its altered force and change instead the principle we first had left untouched. Now I perceive how to use these considerations to establish the intrinsic contradiction I sought. If you believe principle $A$, then you believe that if circumstances and connections of the sort specified in $C$ obtain then you ought to do $Q$; if you believe principle $B$, then you believe that if circumstances and connections of the sort specified in $C$ obtain then you ought not to do $Q$. In other words, you believe on the one hand that if $C$ is true, then you ought to do $Q$, and on the other hand you believe that if $C$ is true, you ought not to do $Q$, hence that it is false that you ought to do $Q$. But you have in this two incompatible beliefs on your hands-incompatible, that is, if $C$ is self-consistent, and this we have agreed to stipulate.

$(\beta)$ But you have forgotten that you are assuming both $A$ and $B$, which are not analytic, in the proof of these two consequence-relations.

$(\alpha)$ Very well, I expand the proof: If $A$, then if $C$, then $Q$; if $B$, then if $C$, then not- $Q$. So, if $A$ and $B$, then if $C$, then $Q$ and not- $Q$. Given $A$ and $B$, then, it follows that $C$ implies $Q$ and not- $Q$. This is a contradiction, necessarily false, since $C$ is non-self-contradictory. Therefore, the assertion of $A$ together with $B$, which implies this contradiction, is necessarily false as well: it is itself a self-contradictory assertion. This shows that $A$ and $B$ are contradictory in themselves. Q.E.D. 
( $\beta$ ) Oh dear! I fear we must clear the whole matter up from its roots, for this is surely fallacious. First, though, I note that though you have said simply "If . . . , then ...." this relation does not carry the burden of your proof if it means "materially implies" in the familiar truthtable sense which makes "implies" equivalent to "not- $P$ or Q." Your proof fails if it rests on this relation alone, as we may see in the assertion that $C$, which implies contradictory assertions, must itself be self-contradictory. It is a well-known fact that a false proposition implies any proposition, in the sense of "implies" in question. Therefore, if your proof has hope of validity you must have meant "logically implies" by "If . . . , then . . . ." With this relation the assertion you made holds true; one may well accept as the definition of "self-contradictory proposition" the definiens "a proposition that logically implies contradictory consequences." Therefore, in this sense you are correct in saying that if $C$ implies contradictory consequences, it is self-contradictory. You are, moreover, correct in saying it does not logically imply any contradictory consequences, because it is non-self-contradictory. But when you say. " $A$ and $B$ logically implies that $C$ logically implies contradictory consequences" you rest in a muddle, a logical confusion. What you are implicitly, or rather half-explicitly doing wrong is this: You begin with the correct statement that the conjunction of $A$ and $B$ and $C$ logically implies $Q$ and not$Q$, i.e., logically contradictory consequences; and you could conclude, correctly again, that therefore $A$ and $B$ and $C$ is a statement that is inconsistent with itself. But you do not merely do this; you go on to say also that therefore $A$ and $B$ logically implies that $C$ logically implies a self-contradictory assertion. This is a fallacy in modal logic. It might be called the fallacy of exportation. It is not true that if the conjunction of $P$ and $Q$ logically implies $R$, it follows that $P$ logically implies that $Q$ logically implies. $R$. What is true and similar is that if the conjunction of $P$ and $Q$ logically implies $R$ 
then $P$ logically implies that $Q$ materially implies $R$. Oh yes, though; I must produce a proof that my key assertion here is true. I do it through a reductio ad absurdum argument. For any $P$, the conjunction of not- $P$ and $P$ logically implies $P$. Now if the exportation rule were true for "logically implies," it would follow from the fact that the conjunction of not- $P$ and $P$ implies $P$, that for any $P$, not- $P$ logically. implies that $P$ logically implies not- $P$. It should be obvious that this involves absurd consequences; and so clearly the exportation rule cannot be accepted for formal implication. This exportation fallacy is quite a natural one, and not too uncommon; and the analogue of the rejected rule does hold for material implication. But as I have already pointed out, use of material implication will not yield the consequences you want.

( $\alpha$ ) You are reducing the issue between us, then, to the question whether $A$ and $B$ together logically imply that $C$ logically implies contradictory consequences.

$(\beta)$ What I have done is to show that you have given no proof of this relation. I have shown in particular that all you have said goes to prove not this contested relation, but merely the statement that the conjunction of $A$ and $B$ and $C$ logically implies $Q$ and not- $Q$. This I accept. But I deny that the contested relation follows from the consequencerelation on which we agree.

\section{Sidgwick's and Ross' Contrasting Treatments of Conflicts in Ethics}

It might seem, then, that we could agree with Ross that ethical principles that involve inconsistent consequences may nonetheless not be inconsistent in themselves, though we have explained more precisely in what sense it can be said that such principles "involve" such consequences, as we have set out under what conditions and with what 
additional assumptions this is so. ${ }^{8}$ But if we are to carry out the hypothesis being developed here, we should contend that Sidgwick need not (and in fact he does not) resort with Ross to the modifications the latter has introduced into the statement of his principles in order to escape the difficulty he finds in these incompatibilities of consequences. Ross does not, moreover, seem always to make the same move here.

A. E. Duncan-Jones gives the account of Ross' doctrine that follows, slightly modified:

... One obligation may override another . . . what is meant to be expressed is . . . that a situation exists-as such situations may often exist-in which there are incompatible obligations; and in such situations we have to discover which is of highest authority.

There is a certain clumsiness of language in our description of these situations; for the statement "you are under an obligation to do $\mathrm{X}$ " might be taken to mean that $\mathrm{X}$ is what is morally required of you, and that no other claim upon you can take away this obligation; or it might be taken as compatible with "you are under an obligation to do $Y$," when $X$ and $Y$ are incompatible with one another, so that we cannot mean to say that both $X$ and $Y$ are morally required. Modern writers, in particular Sir David Ross, have introduced a special terminology to avoid confusion between these two senses of such words as "obligation." They propose that, when by saying that I am under an obligation to do $X$ we do not exclude my being also under an obligation to do $\mathrm{Y}$, which is incom. patible with $X$, we shall speak of the relation in which $\mathrm{I}$ am supposed to stand to $\mathrm{X}$ and $\mathrm{Y}$ as a "prima facie

8 For W. D. Ross' views on prima facie duty, see, for example, The Right and the Good (1930), Chapter II, "What Makes Right Acts Right?" pp. 16-47, especially pp. 18-20, pp. 28-34, pp. 41-42, and p. 46, and Foundations of Ethics, Chapter IV, "Theories about the Ground of Rightness," pp. 57-84, and Chapter V, "The Obligation to Fulfil Promises," pp. 87-113, especially pp. 82-84. 
obligation," or "conditional obligation." But when the statement that I am under an obligation to do $\mathrm{X}$ means that $\mathrm{X}$ is morally required of me, and no competing claim can interfere, we are to say without qualification that to do $\mathrm{X}$ is an obligation, or perhaps that it is a categorical obligation. In this way we can mark systematically the distinction Butler refers to when he speaks of one obligation "superseding" another."

Sidgwick does not agree that "incompatible obligations" can remain actual in the particular case. He appreciates the full force of the argument that the egoistic and utilitarian principles cannot actually both be true if his postulate (or something like it) is not true. He says we cannot systematize conduct on the two principles together without the postulate. This implies, though Sidgwick does not state this, that in a case of actual conflict of principle, apart from the postulate, one of the principles involved must yield to an exception or qualification in order to accommodate it to the other.

We should observe here simply that Sidgwick does not attempt to remove contradictions in ethics, or to alleviate them, in the same manner as Ross. Ross himself seems sometimes to want not to distinguish "senses of 'ought" " but to alter the formulation of the principles that define or determine prima facie duties. Sometimes he insists that the intuitively certain principle about promise-keeping that we express loosely in the assertion "You ought to keep your promises" amounts strictly to the assertion "Acts of promisebreaking have as such, i.e., in virtue of that characteristic, a tendency to be wrong, or such that you ought not to do them." After all we can scarcely suppose he always wants to say that when faced with the assertion that he ought to do such-and-such because that would be an act of promisekeeping, while also faced with the assertion that he ought not to do such-and-such on some other prima facie account,

๑ Austin Duncan-Jones, Butler's Moral Philosophy, 1952, pp. 161-162. 
it is true both that he ought to do such-and-such and that he ought not. No doubt with the rest of us he sometimes feels it can't be. Indeed, Ross sometimes says, in effect, "Have it that way if you will with 'ought,' it's my way with 'obligation.' " This excellent reply he goes on, however, to forget; and it is at this point that we are presented with the doctrine of "tendencies."

Small matter that with his first reply ("It's your way with 'ought' but my way with 'obligation" ") we must still insist on a change in the formulation of the prima facie obligations-for example from "You ought not to lie" to "You are under an obligation not to lie." Small matter as well that some people may still insist that in its brute form, "You ought not to lie," the principle is a deliverance of the common moral consciousness, ignoring both Ross' careful protestation that this is to trespass with intuitive certainties onto a domain that only probable opinion or moral perception ought to or can cover, and or the equally careful reply that makes it impossible to use "ought" in such a proposition to determine, entirely, what a man ought to do in a particular case, in the presence of conflicting obligations.

For Ross seems right that with "obligation," unlike "ought," we do more readily admit conflict of the sort in question. A good example for Ross on this point is a case of conflicting promises. Here it seems plausible to say that the guilty or unfortunate party is "under two conflicting obligations." After all, he has obligated himself to $A$, and he has obligated himself to $B$, ergo . . . " It is of course not altogether unacceptable to say there are "two different things he ought to do" -or so it seems. But it does seem harder to say this with "ought" than with "obligation," and perhaps impossible to say it with "ought" in a perfectly literal and straight-forward sense. "Ought," then, does tend to render the final decision on what to do, coming out of such a conflict-situation. "Obligation" is used to tag the different elements of a moral conflict as well as for the 
expression of rules apart from particular cases of difficulty, though of course this latter function of general statement is also shared by "ought."

At any rate, Ross argues that even when we decide a man ought to keep one promise and not another that conflicts we still think he is under some obligation to make up for breaking the other. Probably he thinks that an obligation cannot derive from a promise if in the fires of decision, the furnaces of "ought," the obligation to keep the promise has entirely melted away. We should also remark his further argument for the sort of distinction we are discussing, which has it that the obligation remains because in a case of conflict of rules we feel compunction and not entirely light-hearted, though also not shame or remorse, in the inevitable breach.

Accepting, then, Ross' implication that there is a distinction of the nature indicated between "ought" and "obligation," the troublesome fact still remains for Ross' theory that we do not obligingly express prima facie obligations always in terms of mere "obligation." Usually, indeed, we say, "You ought . . ." or ". . . ought not." It is this that forces Ross to insist on the reformulation of these duties in terms of "tendencies" to rightness. Sidgwick seems, I repeat, to do nothing of this sort. Evidently this sort of move affords him an escape from the besetting problem of inconsistency between his principles. But he does not see it and does not take it, good escape or not, and feels he has to attempt his postulate in order to reconcile his manifest obligations, the ends of nature and of reason, as at one point he distinguished them. 


\section{RESUMEN}

En Los Métodos de la Ética Henry Sidgwick describe la relación que se da entre "el fin natural de la acción - la felicidad privada, y el fin del deber- la felicidad general" como una "contradicción fundamental" que plantea "el más profundo de los problemas de la Ética".

Sidgwick intenta resolver este problema de dos maneras diferentes: primero, apelando a la intuición para suprimir el egoísmo cuando éste entra en conflicto con el principio de utilidad y, segundo, apelando al postulado de la existencia de sanciones sobrenaturales, el cual elimina el conflicto práctico entre el principio egoísta y el utilitarista.

El presente artículo sólo trata la segunda manera de abordar el problema. Desarrolla una hipótesis acerca del tipo lógico del conflicto que se da entre los dos principios de Sidgwick, la cual es compatible con el uso del postulado de la existencia de sanciones sobrenaturales que se introduce para eliminar el conflicto entre aquellos principios. De acuerdo con esta hipótesis, los principios de Sidgwick no son inmediatamente inconsistentes entre sí, sino que están en contradicción práctica posible y actual. Ninguna contradicción puede ser derivada de la afirmación conjunta de sólo los dos principios; únicamente podría derivarse de la conjunción de los dos principios con otros enunciados contingentes que describen las circunstancias en que los fines de los principios son mutuamente exclusivos. El postulado de Sidgwick eliminaría la inconsistencia práctica actual de los dos principios, de manera que no quedaría ninguna inconsistencia lógica inmediata, sólo permanecerían posibles inconsistencias prácticas.

Esta hipótesis, cuyo objeto es eliminar aquella aparente "contradicción fundamental" y convertirla en un conflicto indirecto, es defendida contra objeciones que descansan en la falacia de exportación. También hay el intento de distinguirla de otra posible manera de remover el conflicto entre los principios de Sidgwick la cual es sugerida por W.D. Ross cuando distingue entre obligaciones prima facie y obligaciones incondicionales. En la explicación de Ross en términos de las diferencias que establece entre el uso del verbo "deber" y el de la palabra "obligación", se encuentran tanto virtudes como defectos. El verbo "deber", y no la palabra "obligación", suele ser usado para expresar la resolución de una 
perplejidad moral; "obligación", en cambio, suele usarse solamente para expresar ciertos elementos conflictivos que intervienen en estas perplejidades. A pesar de las virtules del intento de Ross, cabe notar que Sidgwick en ningún momento usa nociones tales como "obligación prima facie" para resolver el conflicto entre sus principios.

Este artículo no establece de manera definitiva los méritos de la hipótesis que presenta; pero sí representa un desafío a la acep. tación sin crítica de la tesis según la cual los principios de Sidgwick son irremediablemente incompatibles. 